\title{
The role of strong-tie social networks in mediating food security of fish resources by a traditional riverine community in the Brazilian Amazon
}

\author{
$\underline{\text { Frédéric Mertens }}^{1,2,3}, \underline{\text { Myriam Fillion }}^{1,3,4}$, Johanne Saint-Charles $^{3,5}$ Pierre Mongeau $^{5}$, Renata Távora $^{2}$, Carlos José Sousa Passos $^{2,3,6}$
} and Donna Mergler ${ }^{3}$

\begin{abstract}
Social networks are a significant way through which rural communities that manage resources under common property regimes obtain food resources. Previous research on food security and social network analysis has mostly focused on egocentric network data or proxy variables for social networks to explain how social relations contribute to the different dimensions of food security. Whole-network approaches have the potential to contribute to former studies by revealing how individual social ties aggregate into complex structures that create opportunities or constraints to the sharing and distribution of food resources. We used a whole-network approach to investigate the role of network structure in contributing to the four dimensions of food security: food availability, access, utilization, and stability. For a case study of a riparian community from the Brazilian Amazon that is dependent on fish as a key element of food security, we mapped the community strong-tie network among 97\% of the village population over 14 years old ( $\mathrm{n}=336$ ) by integrating reciprocated friendship and occupational ties, as well as close kinship relationships. We explored how different structural properties of the community network contribute to the understanding of (1) the availability of fish as a community resource, (2) community access to fish as a dietary resource, (3) the utilization of fish for consumption in a way that allows the villagers to maximize nutrition while at the same time minimizing toxic risks associated with mercury exposure, and (4) the stability of the fish resources in local ecosystems as a result of cooperative behaviors and community-based management. The contribution of whole-network approaches to the study of the links between community-based natural resource management and food security were discussed in the context of recent social-ecological changes in the Amazonian region.
\end{abstract}

Key Words: Amazon; common property regimes; community-basedmanagement; fish consumption; food security; mercury; natural resource management; social networks; strong ties

\section{INTRODUCTION}

The Food and Agriculture Organization of the United Nations (FAO) defines food security as existing "when all people, at all times, have physical, social and economic access to sufficient, safe and nutritious food that meets their dietary needs and food preferences for an active and healthy life" (FAO 2010:8). This definition encompasses four main dimensions: availability, access, utilization, and stability (Barret 2010, FAO 2010). Availability occurs when the population has sufficient food supplies from which to choose. Access is related to the ability of individuals and households to effectively obtain food through purchase on the marketplace or from other sources, such as exchanges or gifts, according to their social and economic conditions. Utilization embraces ideas about whether individuals make use of the food to which they have access in a way that allows them to achieve dietary quality, e.g., through the choice of nutritionally balanced food and healthy forms of food preparation. Stability is a crosscutting dimension that relates to the long-term availability, access, and healthy utilization of the food over time.

Along with market exchanges and the institutional distribution of services and goods, social ties and networks are a significant way through which people obtain resources (Wellman and Wortley 1990), including food aid and other resources, to secure adequate levels of food for themselves and their families (Ahluwalia et al. 1998). Food security was found to be correlated with network-related variables in diverse studies, e.g., with levels of social interactions with neighbors, friends, and family members in Peru (Díaz et al. 2002); with the number of close friends of the head of the household in Burkina Faso (Becquey et al. 2012); with attendance of social events and church used as proxy measures of social networks in a Puerto Rican community (Dhokarh et al. 2011); and with the perception that an individual's neighborhood was helpful and trustworthy in a U.S. study (Walker et al. 2007). In studies on coping mechanisms to address food insecurity, reliance on social support provided by extended family members, friends, or neighbors has been identified in several geographic and social contexts, including AIDS-afflicted households in rural Malawi (Mtika 2001); an Inuit coastal community in the Canadian High Arctic (Beaumier and Ford 2010); and lowincome households from North Carolina, USA (Ahluwalia et al. 1998).

Previous studies linking social networks and food security have mostly used egocentric network data, i.e., network relations surrounding individuals or households, or proxy variables for social networks. Whole-network approaches have the potential to add to these former studies by revealing how individual social ties aggregate into complex structures that create opportunities or constraints to the sharing and distribution of food resources at the community level (Marin and Wellman 2011). In our research, we use a whole-network approach to investigate the role of the

${ }^{1}$ Centro de Desenvolvimento Sustentável, Universidade de Brasília, ${ }^{2}$ Community of Practice in Ecosystem Approaches to Health in Latin America and the Caribbean (CoPEH-LAC), ${ }^{3}$ Centre de recherche interdisciplinaire sur le bien-être, la santé, la société et l'environnement (CINBIOSE), Université du Québec à Montréal, ${ }^{4}$ Department of Biology, University of Ottawa, ${ }^{5}$ Faculté de communication, Université du Québec à Montréal, ${ }^{6}$ Faculty UnB Planaltina, University of Brasília 
network structure in mediating food security. To achieve this goal, we present a case study focusing on a traditional riverine community from the Tapajós River region in the Brazilian Amazon.

In riverine communities of the Brazilian Amazon, although agriculture may provide fruits, vegetables, rice, beans, and, less frequently, chicken or beef meat, the bulk of the population's diet includes only two components: cassava (Manihot spp.), easily stored as flour and a source of carbohydrate that offers $70 \%$ to $80 \%$ of dietary energy, and fish, the main source of protein and essential nutrients (Dorea 2003, Adams et al. 2005). Fishing is a major social, economic, and cultural activity for traditional riverine communities of the Tapajós River region, and fish can be considered the central component of their diet (Passos et al. 2003, 2007a, Sampaio da Silva et al. 2011).

In the Brazilian Amazon, fish resources are mostly managed under common property regimes (McGrath et al. 2007, Ostrom and Hess 2007). Scholarship on common pool resource management has shown that communities, under certain circumstances, are capable of cooperating and self-organizing to sustainably govern resources on which they depend (Agrawal 2001). There is also a large literature on fisheries management showing that communities have been able to create institutional arrangements based on participatory decision making that foster equitable and sustainable use of the fish resources (Berkes 2003). For example, in the Lower Amazon, communities were successful in implementing comanagement agreements to regulate the exploitation of floodplain lake fisheries that have been effective in securing productivity and conservation benefits for local resource users (Almeida et al. 2009). Social network analysis has been useful to map and analyze the linkages between comanagement collaborative structures and the adaptive capacity of communities in the management of fish resources under common property regimes (Sandström and Rova 2010).

We analyzed the set of activities associated with the management, catch, and use of fish resources to investigate the relations between community network structure and food security. By focusing on only one key community resource, it is possible to differentiate precisely among the four dimensions associated with food security. Our main objective was to use a whole-network approach to explore how the structural properties of social networks among inhabitants from a riverine Amazonian community from the Tapajós River region can contribute to fish resources availability, access, utilization, and stability.

We begin by presenting the ecological and social contexts of fishrelated activities in traditional riverine Amazonian communities from the Tapajós region and how individuals' social ties shape the diversity of practices associated with the use and sharing of the fish resources. We then present social network analysis as the conceptual and methodological approach chosen to study community networks in one village case study. Results are presented linking structural characteristics of the community social networks to the dimensions of fish resource availability, access, utilization, and stability. We discuss the contributions of applying a whole-network approach in studies on community food security and the implications of the results in the context of recent regional environmental and social changes in the Amazonian region. Limitations of the research and suggestions for future investigation are presented.

\section{Fish-related activities in traditional riverine Tapajós Amazonian communities}

Traditional Amazonian riverine communities refer to small villages, usually including no more than a few hundred inhabitants, located on the bank of a river or a lake and that originated from the miscegenation of old indigenous populations with European colonizers and, to a lesser extent, with African slaves during the 18th and 19th centuries (Murrieta 2001). Several dozen communities live on the banks of the mid-Tapajós River, a major tributary of the Amazon River, Brazil (Fig. 1).

Fig. 1. Map of the study region.

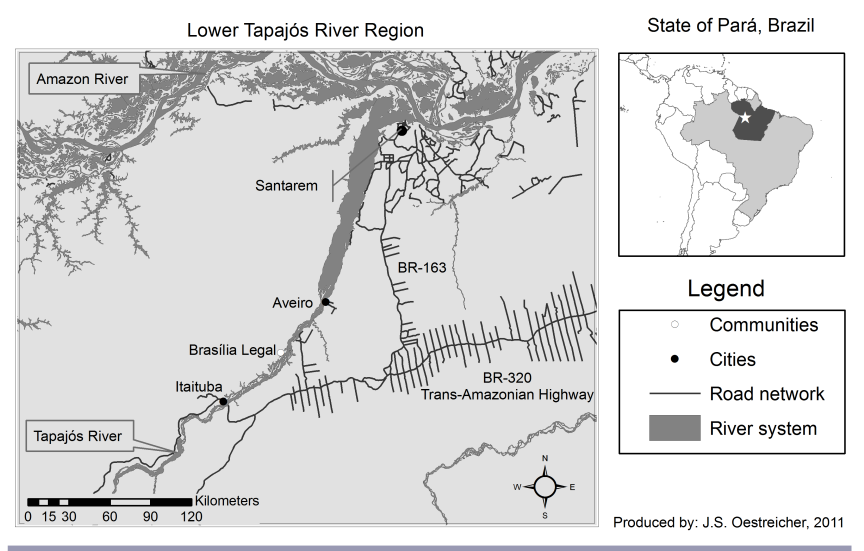

The fish-related activities of traditional riverine Tapajós communities can be described from a perspective that emphasizes the role of social ties in the use and sharing of the fish resources. Descriptions are based on previous research by Sampaio da Silva (2008) and Sampaio da Silva et al. (2011) carried out in 12 riverine communities during 2003 as well as on research notes taken by the authors during several months of fieldwork in the region between 1998 and 2006.

At the time of our study (2004), most riverine communities located between the cities of Aveiro and Itaituba in the midTapajós region (Fig. 1) had fish as an abundant and diverse natural resource. The sustainability of fish resources over decades of fishing activities could be linked to two main factors: the isolation of the communities and community-based management arrangements that promote the distribution of fishing activities among the diverse aquatic ecosystems surrounding the villages. Fishing takes place in diverse locations around the villages, including the main river watercourse, small tributary rivers (called igarapés), and several types of lakes that may be connected to the main watercourse either permanently or temporarily during the rainy season. The ability to explore diverse ecosystems and fish species is based on the use of different techniques and fishing gear types, including gill nets, hand lines, bottom lines, cast nets, harpoons, tridents, and bow-fishing arrows. These practices allow the communities to take advantage of the large diversity of fish species. Indeed, between 19 and 24 fish species were reportedly caught on a regular basis in the region (Sampaio da Silva 2008).

Fishing is a collaborative community-based activity, and fish is managed under a common property regime. Ecological knowledge and fishing techniques are generally transmitted from father to son or grandfather to grandson. Fishers usually use small wooden canoes to fish in pairs or in small groups frequently 
composed of close friends or family members or, alternatively, their wives. At the end of a fishing expedition, the catch is often shared equally among group members. Beyond the specific task of catching fish, fish-related activities include driving small boats, preparing baits, fixing fishing nets, cleaning fish, and preparing fish meals. These supportive activities are usually women's tasks, carried out by the spouse, the mother, or sisters, sometimes by a brother, but very rarely by persons outside the nuclear family circle.

The selection of fish for family consumption depends on several factors, including food preference, fish availability, and conditions that determine access to the fish resources. Fish consumption is also determined by a complex decision-making process involving social ties because fish consumption in this area is simultaneously associated with benefits and risks to health (Mertens et al. 2012). Although fish is a very nutritious food and contains many nutrients, including minerals, vitamins, and omega- 3 fatty acids that foster good health, many fish also bioaccumulate contaminants, such as methyl mercury, dioxins, and persistent organic pollutants (Mahaffey 2004, Gochfeld and Burger 2005). In the mid-Tapajós River basin, mercury is present in the aquatic ecosystems as a consequence of deforestation and "slash-andburn" agricultural practices that cause intensive erosion of soils rich in naturally occurring mercury (Roulet et al. 2000). As a result of the bioaccumulation and concentration of the contaminant in the aquatic food web, higher trophic-level fish from the Tapajós waters frequently have elevated levels of methyl mercury, a potent neurotoxin (Sampaio da Silva et al. 2005, Mergler et al. 2007). For the fish-eating communities living along the Tapajós River, bioindicators of mercury exposure, i.e., mercury in blood and hair, increase with increased fish consumption (Lebel et al. 1998, Passos and Mergler 2008), and villagers are at risk of a variety of adverse health effects associated with their exposure (Passos and Mergler 2008, Fillion et al. 2011).

Communities thus face the challenge of adapting their fish diet behavior to maximize nutrition from fish while at the same time minimizing toxic risks associated with mercury exposure (Fillion et al. 2011, Mertens et al. 2012). The high local fish biodiversity allows the population to choose among many different fish species for consumption. Mercury concentrations vary widely among fish species, the highest mercury levels being consistently found in carnivorous species and the lowest in herbivorous species (Lebel et al. 1997, Sampaio da Silva et al. 2005). Which fish species end up being eaten by household members is dependent on a decisionmaking process that involves gender-dependent activities (SaintCharles et al. 2012). Indeed, family fish consumption relies on how men orient their fishing activities and define which fish are sold, exchanged, or kept for family consumption and how women select fish species to be included in the preparation of the daily meals. These activities and behavior choices determine dietary quality and are associated with relational processes, such as information exchanges and discussion between spouses, among social groups, and in villages' social networks (Mertens et al. 2005, 2008). For instance, households in which spouses discuss mercury issues are more likely to orient fish consumption toward the lesscontaminated fish species (Mertens et al. 2012).

The management, catching, sharing, and use of fish resources in riverine Tapajós communities can thus be described as a social process that relies on several types of ties that include friendship ties, e.g., the sharing of a fish catch; occupational ties, e.g., fishers fishing in pairs or small groups; and kinship ties, e.g., fathers teaching fishing practices or spouses negotiating the fish diet. Fish-related activities can also be differentiated according to the four dimensions of food security: availability, access, use, and stability. Availability of the fish resources can be considered both at the ecosystem level, as a natural resource, and at the community level, through fishing practices. Access to the fish resources is determined by the patterns of distribution, sharing, exchanges, and sale of the catch among community members. Utilization of the fish involves dietary behavior choices aimed at reducing toxic exposure and maximizing benefits from fish consumption. Finally, stability at the annual level involves the ability of the villagers to secure fish meals throughout the year despite seasonal variations in fish species availability, whereas the longer term stability of the fish resource over decades is dependent on the level of sustainability of the management practices. To bring together social network analysis and food security, one riverine village from the mid-Tapajós region was chosen to further explore how friendship, occupational, and kinship ties aggregate into a complex community social network and how the structural properties of this network can contribute to explain fish resource availability, access, utilization, and stability.

\section{METHODS}

\section{Study population}

The research was conducted in the community of Brasilia Legal, a traditional riverine village founded in 1835 and located on the left bank of the Tapajós River in the state of Pará, Brazilian Amazon (Fig. 1). The research team conducted a house-to-house survey in 2004, which revealed that the village had a total population of 557 people living in 118 households, among which 347 , those aged at least 14, were invited to participate in the study. Although the minimum legal age is 18 in Brazil, individuals between 14 and 17 years old were included in the study because it is not unusual to observe new households being established by individuals under 18 and because many young individuals were actively involved in fishing activities. Data were collected for a total of 336 individuals ( $97 \%$ of the target population); 11 could not be interviewed because of severe health problems or because they were temporarily living outside the village. Semistructured face-to-face interviews covering standard demographic characteristics, fishing practices, mercury-exposure-related questions, and network questions were conducted privately at the home of each participant in October and November of 2004. In addition, a 7-day dietary recall questionnaire was used to determine fish consumption frequency with a sample of the village population $(n=68)$ that also participated in a study examining blood and urinary mercury levels and the factors influencing their concentration (Passos et al. 2007b).

The socio-demographic characteristics of the population of Brasilia Legal are presented in Table 1. The age distribution is pyramidal, with $46 \%$ of the villagers being 30 years old or younger. Inhabitants of the community were mostly born in the state of Pará, with $79 \%$ of the population from the Tapajós region and $44 \%$ born in the village. Most young individuals have spent all of their lives in the community, and almost half of the inhabitants have lived in the village for at least 20 years. The formal 
Table 1. Frequency distributions ( $\%)$ of socio-demographic characteristics of the participants in the study by gender. $\chi^{2} \mathrm{p}:{ }^{*} \mathrm{p}<0.05$, ${ }^{* *}$ $\mathrm{p}<0.01, * * * \mathrm{p}<0.001$ between men's and women's groups.

\begin{tabular}{|c|c|c|c|}
\hline & $\begin{array}{c}\text { All } \\
(\mathrm{n}=336)\end{array}$ & $\begin{array}{c}\text { Men } \\
(\mathrm{n}=175)\end{array}$ & $\begin{array}{c}\text { Women } \\
(\mathrm{n}=161)\end{array}$ \\
\hline \multicolumn{4}{|l|}{ Age } \\
\hline $14-20$ & 24 & 22 & 27 \\
\hline $21-30$ & 22 & 22 & 22 \\
\hline $31-40$ & 15 & 17 & 14 \\
\hline $41-50$ & 13 & 14 & 13 \\
\hline $51-60$ & 12 & 12 & 11 \\
\hline $61-70$ & 8 & 10 & 7 \\
\hline $71-80$ & 4 & 3 & 5 \\
\hline $81-90$ & 1 & 1 & 1 \\
\hline $91-100$ & 0.3 & 0.6 & 0 \\
\hline \multicolumn{4}{|l|}{ Region of origin } \\
\hline \multicolumn{4}{|l|}{ Pará state } \\
\hline Brasília Legal & 44 & 49 & 39 \\
\hline Other communities from the Tapajós region & 35 & 31 & 39 \\
\hline Other regions of the Pará state & 13 & 12 & 15 \\
\hline Outside the Pará state & 7 & 7 & 8 \\
\hline \multicolumn{4}{|l|}{ Time living in the community } \\
\hline $1-10$ & 22 & 21 & 24 \\
\hline $11-20$ & 32 & 29 & 34 \\
\hline $21-30$ & 15 & 17 & 14 \\
\hline $31-40$ & 9 & 11 & 6 \\
\hline $41-50$ & 7 & 7 & 6 \\
\hline $51-60$ & 7 & 8 & 6 \\
\hline $61-70$ & 4 & 4 & 4 \\
\hline $71-80$ & 2 & 1 & 3 \\
\hline $81-90$ & 0.3 & 0 & 0.6 \\
\hline $91-100$ & 0.3 & 0.6 & 0 \\
\hline No data & 1 & 1 & 2 \\
\hline \multicolumn{4}{|l|}{ Education* } \\
\hline 0 & 10 & 12 & 8 \\
\hline $1-6$ (primary) & 52 & 58 & 46 \\
\hline 7-12 (secondary) & 37 & 29 & 45 \\
\hline 13-15 (graduate) & 1 & 1 & 1 \\
\hline \multicolumn{4}{|l|}{ Main occupation*** } \\
\hline Agriculture/cattle raising & 12 & 21 & 1 \\
\hline Fishers & 7 & 14 & 0 \\
\hline Housewife & 24 & 0 & 49 \\
\hline Retired & 5 & 7 & 2 \\
\hline School & 6 & 3 & 9 \\
\hline Services & 28 & 38 & 16 \\
\hline Students & 17 & 13 & 20 \\
\hline No occupation & 2 & 3 & 1 \\
\hline \multicolumn{4}{|l|}{ Fishing practices $* * *$} \\
\hline Commercial fishers & 9 & 17 & 0 \\
\hline Consumption fishers & 27 & 49 & 4 \\
\hline Fish with husband & 5 & 0 & 11 \\
\hline Do not fish & 59 & 34 & 86 \\
\hline Total & 100.0 & 100.0 & 100.0 \\
\hline
\end{tabular}

educational level is low. Indeed, $62 \%$ of the respondents had no opportunity to study beyond the primary school level. The main occupational activities of the villagers, besides taking care of the house and children, are services, agriculture, and fishing. Services include a diverse set of activities such as driving boats for local or regional transportation, managing small shops, building and remodeling houses, taking care of other people's houses, and working at the health center.

\section{Network data and measures}

Social network analysis is an approach that offers conceptual and methodological tools to study how patterns of interactions between individuals contribute to explain social life (Marin and Wellman 2011). Social networks are analyzed through the integration of attributive data, i.e., the characteristics of the individuals, and relational data, i.e., the relations between them (Scott 2000). Social network analysis has recently emerged in the field of natural resource management (Bodin and Prell 2011) as 
a useful approach to study social capital in small-scale fisheries (Marín et al. 2012), information-sharing networks among fishers (Turner et al. 2014), and environmental governance systems (Crona and Bodin 2010, Sandström and Rova 2010, Mertens et al. 2011), among others. We adopted a whole-network approach, which aims at mapping the relations between all the individuals of a population, because it is adapted to the study of a community with clearly defined boundaries. Individuals were asked about network partners living in the village, based on three different social relations: friendship (who are your friends?), occupation (with whom do you work?), and kinship (who are your relatives?).

We focus on strong ties for two reasons. Tie strength can be defined as a combination of the amount of time, the emotional intensity, the intimacy, and the reciprocal services associated with the relationship (Granovetter 1973). First, it is extremely likely that in a small, isolated community, as is the case for traditional Tapajós communities, each individual is connected to most others through some type of weak tie. Consequently, it is probable that analyzing the weak-ties social network would not reveal any meaningful pattern. Second, we consider that social features mostly associated with strong ties, such as trust, exchanges, and willingness to cooperate in the context of community-based natural resource management under common property regimes, might play an important role in the processes of accessing and sharing a natural resource that is essential for food security and better health (Bebbington and Perreault 1999, Woolcock and Narayan 2000, Pretty and Ward 2001, Bodin and Crona 2009, Prell et al. 2009). Reciprocated ties are more likely to indicate a stronger relationship and have been used as an empirical indicator of strong ties in several previous studies (Granovetter 1973, Marsden and Campbell 1984, Haythornthwaite 1996, Rogers 2003, Kossinets and Watts 2006), including in the fisheries comanagement literature (Sandström and Rova 2010). Therefore, only reciprocated ties among pairs of individuals, e.g., individual A named individual B and individual B also named individual $\mathrm{A}$, were included in the building of the strongtie friendship and occupational networks. To map the strong-tie kinship network, only close kin relationships were included: between parents and children, brothers and sisters, or between spouses. Network data were stored as actor-by-actor matrices using the UCINET software (Borgatti et al. 2002). Because individuals interact with each other on a variety of social dimensions simultaneously (Wellman and Wortley 1990), and because the three types of ties have the potential to play a role in resource and information exchanges related to fishing activities, the three networks were combined, using the matrix operation function of UCINET, to reveal the overall social connectivity in the community. This network integrating the friendship, occupational, and kinship relationships was named the "community strong-tie" network, or the CST network, and was exported to the Netdraw software (Borgatti 2002) to visualize network structures.

Relevant resources that can flow in the CST network within the context of fish-related activities are of two types: information, e.g., on fishing techniques or on mercury exposure from fish consumption, and the fish resources themselves. We examined two network properties to assess the flow of resources in the CST network: the level of fragmentation of the network and the average distance between individuals (Wasserman and Faust 1994). For a resource to be able to flow from one individual to another in a network, the two have to be connected, either directly or through some other people. If there is a path between every pair of individuals, the network is said to be connected, and resources can potentially flow between all pairs of individuals. Alternatively, if the network is composed of several distinct subsets in which there is no path between the individuals of the different subsets, it is said to be fragmented. These subsets are called components, and resources can circulate only between the individuals belonging to the same component but not between the individuals belonging to different components (Wasserman and Faust 1994). The distance between two individuals is defined as the number of links in the shortest path between them (Wasserman and Faust 1994). Average distances can be calculated between every pair of individuals to assess the potential circulation of resources at the level of the entire network or, alternatively, between selected categories of individuals to evaluate the potential flow of resources between subgroups. Short average distances are believed to promote efficient circulation of resources, allowing them to flow between individuals with only a small number of intermediaries. The level of fragmentation of the networks and the distances between individuals were calculated using the UCINET software (Borgatti et al. 2002).

\section{Utilization of the fish resources}

To make a healthy utilization of the fish resource, villagers have the opportunity to direct their fish consumption to species with lower mercury concentrations. Villagers were categorized according to three stages regarding the process of change in diet behavior to reduce mercury exposure: unawareness, awareness, and action. Individuals at the unawareness stage do not have information on the pattern of mercury accumulation in fish. Awareness was measured as a binary variable regarding whether the respondent knew about the difference in mercury accumulation between herbivorous and carnivorous fish and was able to distinguish between these two groups by providing an example of at least one species in each category among the fish found in the Tapajós region. Action was measured as a binary variable regarding whether the respondent said that he/she has modified his/her fish consumption with the objective to reduce mercury exposure and was able to explain how this change was achieved.

\section{RESULTS}

\section{Characterization of the strong-tie networks}

Tables 2 and 3 show the main structural characteristics of the friendship, occupational, and kinship strong-tie networks. The friendship and occupational networks share high levels of fragmentation into numerous isolates (126 and 169, respectively) and into small components, with a size ranging from 2 to 29 for the friendship network and 2 to 30 for the occupational network. Although the kinship network also exhibits a significant level of fragmentation (18 isolates and 27 small components), it has a major component that links close to $50 \%$ of the individuals. The CST network, integrating the friendship, occupational, and kinship relationships, is shown in Figure 2. Individuals are connected by lines of different colors and sizes according to the type of relation and the multiplexity of the tie; a tie is multiplex when it involves more than 1 type of social relation, e.g., when there is a friendship relation between 2 coworkers. Because 9 links include all 3 social relations and 104 include 2 of them, the number of links of the CST network is only 793, whereas the sum of the 
number of links of the 3 single-relation networks is 915 (Table 2). Most of the villagers (98\%) are connected to one another in a single cluster (Tables 2 and 3; Fig. 2). Only 3 individuals are isolated, and there is only 1 small component consisting of a connected triad. We now turn to analyzing fish resource availability, access, utilization, and stability in the village for exploring how community network features may contribute to an explanation of these aspects of food security.

Fig. 2. The community strong-tie network. Individuals are represented according to a code of shapes and colors: men (square), women (circle), commercial fishers (dark blue), consumption fishers (light blue), and rest of the population (gray). Friendship, occupation, kinship, and multiple relations are, respectively, shown in green, blue, red, and gray. Links involving two and three types of relations are, respectively, twice and three times as large as the links involving only one.

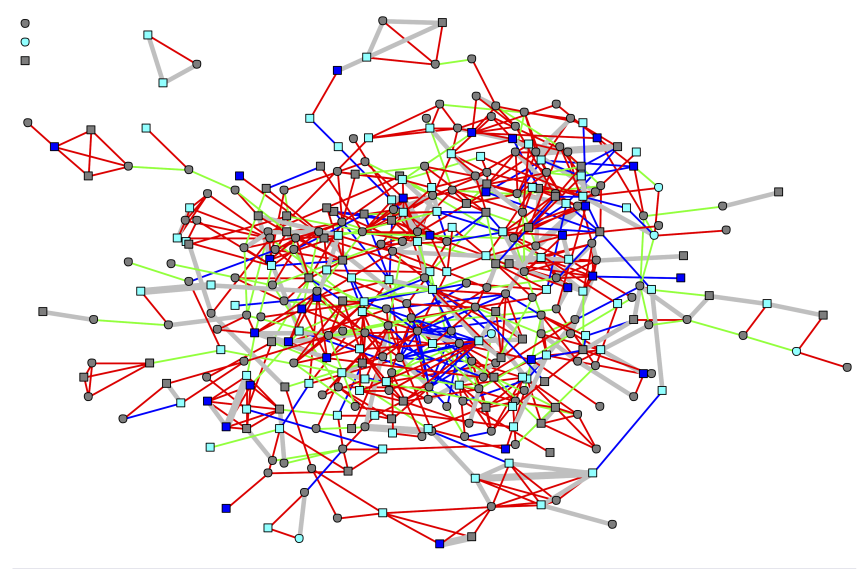

Table 2. Main characteristics of the strong-tie networks.

\begin{tabular}{|c|c|c|c|c|}
\hline & Friendship & $\begin{array}{l}\text { Occupa- } \\
\text { tion }\end{array}$ & Kinship & $\mathrm{CST}^{\dagger}$ \\
\hline Number of villagers & 336 & 336 & 336 & 336 \\
\hline $\begin{array}{l}\text { Number of relations among } \\
\text { villagers }\end{array}$ & 177 & 167 & 571 & 793 \\
\hline $\begin{array}{l}\text { Mean number of relations per } \\
\text { villager }\end{array}$ & 1.05 & 0.99 & 3.40 & 4.72 \\
\hline $\begin{array}{l}\text { Range of the number of } \\
\text { relations per villager }\end{array}$ & $0-5$ & $0-9$ & $0-12$ & $0-16$ \\
\hline Isolates ${ }^{*}$ & 126 & 169 & 18 & 3 \\
\hline Small components ${ }^{\S}$ & 42 & 42 & 27 & 1 \\
\hline \multicolumn{5}{|c|}{$\begin{array}{l}\text { CST, community strong-tie. } \\
{ }^{+} \text {An isolate is an individual with no relation to any other individual in } \\
\text { the network. } \\
{ }^{\$} \text { A component is a subset of individuals who are connected, either } \\
\text { directly or through some other individuals. }\end{array}$} \\
\hline
\end{tabular}

\section{Availability of the fish resources}

Availability of fish encompasses two dimensions: fish should be available as a natural resource in the surrounding environment but also available as a community resource through fishing practices. Evidence from previous studies indicates that in 2004 fish was an abundant and diverse natural resource in the aquatic ecosystems of Brasília Legal. A fish inventory carried out using the same type of fish net as the local fishers at the usual Brasília Legal fishing sites revealed as many as 40 different species (Lebel et al. 1997). In another study, fishers from the community identified 43 different species suitable for human consumption in the village (Fillion et al. 2011). In addition, our data show (Table 1) that in 2004, fish stocks were still able to sustain the fishing practices of two-thirds of the men. Fishers were distributed into two categories: consumption fishers who preferentially kept their catch for household consumption and commercial fishers who used to sell their catch to regional markets outside the community. Both groups also frequently shared or exchanged part of their catch with relatives, friends, and neighbors. The richness of the resource in the environment combined with the high number of fishers in the community supports the assumption that fish was available both as a natural and a community resource.

Table 3. Distribution of component size of the strong-tie networks.

\begin{tabular}{ccccc}
\hline \hline Component $^{\dagger}$ size & Friendship & Occupation & Kinship & $\begin{array}{c}\text { CST }^{\ddagger} \\
\text { network }\end{array}$ \\
\hline 330 & 0 & 0 & 0 & 1 \\
167 & 0 & 0 & 1 & 0 \\
30 & 0 & 1 & 0 & 0 \\
29 & 1 & 1 & 0 & 0 \\
23 & 0 & 0 & 1 & 0 \\
18 & 1 & 0 & 0 & 0 \\
16 & 0 & 0 & 1 & 0 \\
15 & 1 & 0 & 1 & 0 \\
14 & 1 & 0 & 0 & 0 \\
13 & 0 & 0 & 1 & 0 \\
11 & 1 & 0 & 1 & 0 \\
8 & 1 & 0 & 2 & 0 \\
7 & 3 & 0 & 0 & 0 \\
6 & 1 & 1 & 0 & 0 \\
5 & 3 & 2 & 2 & 0 \\
4 & 5 & 4 & 3 & 0 \\
3 & 5 & 10 & 5 & 1 \\
2 & 19 & 23 & 10 & 0 \\
1 & 126 & 169 & 18 & 3 \\
\hline
\end{tabular}

${ }^{\dagger}$ A component is a subset of individuals who are connected, either directly or through some other individuals.

${ }^{\ddagger} \mathrm{CST}$, community strong-tie.

\section{Access to the fish resources}

For the whole community to benefit from the available fish resources, the catch should be made accessible to all or most inhabitants. The fish caught is used for household consumption but is also shared with relatives and friends and with other villagers who lack access to this resource, such as single mothers or older individuals. A catch can also be exchanged for services or goods, e.g., agricultural products or medicinal plants. Fish are rarely sold among members of the community because most families have very limited availability of cash. Professional fishers, however, sell part of their catch to middlemen or directly to fish markets from Itaituba, the neighboring city (Fig. 1) to contribute to household earnings.

It is reasonable to assume that a strong tie to a fisher, either directly or through very few intermediates, will facilitate access to the fish resources. To evaluate the accessibility of the fish resources at the community level, the frequency distributions of the distances 
Table 4. Distance frequency distributions and mean distance between fishers and the villagers in the main component of the community strong-tie network $(n=330)$.

\begin{tabular}{|c|c|c|c|c|c|c|}
\hline \multirow[b]{3}{*}{ Distance } & \multicolumn{6}{|c|}{ Distance frequency distribution from } \\
\hline & \multicolumn{2}{|c|}{$\begin{array}{l}\text { Commercial fishers } \\
(n=29)\end{array}$} & \multicolumn{2}{|c|}{$\begin{array}{l}\text { Consumption fishers } \\
(\mathrm{n}=89)\end{array}$} & \multicolumn{2}{|c|}{$\begin{array}{l}\text { All fishers } \\
(\mathrm{n}=118)\end{array}$} \\
\hline & $\begin{array}{l}\text { Number of } \\
\text { individuals } \\
(\mathrm{n}=301)\end{array}$ & $\%$ & $\begin{array}{l}\text { Number of } \\
\text { individuals } \\
(\mathrm{n}=241)\end{array}$ & $\%$ & $\begin{array}{l}\text { Number of } \\
\text { individuals } \\
(\mathrm{n}=212)\end{array}$ & $\%$ \\
\hline 1 & 88 & 29 & 169 & 70 & 172 & 81 \\
\hline 2 & 113 & 38 & 63 & 26 & 37 & 17 \\
\hline 3 & 73 & 24 & 8 & 3 & 3 & 1 \\
\hline 4 & 18 & 6 & 1 & 0.4 & & \\
\hline 5 & 8 & 3 & & & & \\
\hline 6 & 1 & 0.3 & & & & \\
\hline Mean distance & \multicolumn{2}{|c|}{2.2} & \multicolumn{2}{|c|}{1.3} & \multicolumn{2}{|c|}{1.2} \\
\hline
\end{tabular}

between fishers and the remaining individuals in the main component of the CST network $(n=330)$ were calculated (Table 4). The villagers were distributed at very short distances to both categories of fishers. On average, there was only 1 intermediate between commercial fishers and the villagers. Seventy percent of the villagers had a direct connection to at least 1 consumption fisher. The average distance between community members and a fisher of either category was only 1.2.

\section{Utilization of the fish resources}

Fish consumption levels were obtained through a dietary survey with a subsample of the study population (Table 5). Over the preceding 7 days, individuals ate, on average, 5.3 fish meals, and $90 \%$ of the population consumed at least 1 meal with fish. Eighteen different fish species were included in those meals. Although men consumed more fish meals than women, the difference is not statistically significant. As in other riverine communities of the Tapajós region, fish could thus be considered the central source of protein for the villagers of Brasília Legal. Villagers usually complemented their protein diet with chicken or eggs. In 2004, beef meat was scarcely available as a source of protein to most villagers, as only 1 cow used to be killed each month and as beef meat was accessible only to the people at the highest economic level.

We also analyzed the possible role of strong ties in the utilization of the fish resources in a way that would allow the community to take advantage of fish as an essential source of proteins and nutrients while at the same time minimizing the toxic risks associated with chronic methyl mercury exposure. Previous studies have shown that information on mercury issues within the context of diet, health, or fishing are widely discussed among villagers from this community (Mertens et al. 2005, 2012). Strong ties might be associated with changes in fish consumption patterns because they may contribute to added trustworthiness about information on mercury issues and motivate people to act accordingly to reduce their exposure to the contaminant. We compared the mean number of strong ties in the CST network among the villagers who are at the unawareness, awareness, or action stage regarding change in dietary behavior to reduce mercury exposure. The mean number of strong ties increased among the individuals from the unawareness $(4.9, \mathrm{n}=179)$ to the awareness $(5.6, \mathrm{n}=103)$ and action $(7.0, \mathrm{n}=54)$ stages. There was no statistically significant difference in the mean number of strong ties between individuals at the unawareness and awareness stages ( $p>0.05$ unpaired t-test). However, the mean number of strong ties for the individuals at the action stage was significantly higher than for individuals at the unawareness $(p<0.0001$, unpaired $t-$ test) and awareness ( $p<0.05$, unpaired t-test) stages.

Table 5. Frequency distributions (\%) of fish meals/week according to gender.

\begin{tabular}{lccc}
\hline \hline & $\begin{array}{c}\text { All } \\
(\mathrm{n}=68)\end{array}$ & $\begin{array}{c}\text { Men } \\
(\mathrm{n}=22)\end{array}$ & $\begin{array}{c}\text { Women } \\
(\mathrm{n}=46)\end{array}$ \\
\hline Fish meals & & & \\
0 & 10 & 14 & 9 \\
$1-3$ & 32 & 27 & 35 \\
$4-6$ & 22 & 9 & 28 \\
$7-9$ & 15 & 14 & 15 \\
$10-12$ & 18 & 32 & 11 \\
$13-15$ & 3 & 5 & 2 \\
Total & 100 & 100 & 100 \\
Mean & 5.3 & 6.1 & 4.9 \\
\hline
\end{tabular}

\section{Stability of the fish resources}

The widespread availability of fish in 2004 suggests that the population has been able to sustainably manage the resources over decades of fishing activities. Strong ties among fishers may have contributed to the stability of fish resources because they are likely to enhance cooperative behaviors, favor the establishment of collective norms, and foster trust to invest in sustainable management activities (Pretty and Ward 2001, Bodin and Crona 2009). Table 6 presents the distribution of ties among the commercial, consumption, and nonfisher groups in the friendship, occupational, kinship, and CST networks. Ties were not distributed homogeneously among groups $\left(\chi^{2} p<0.001\right)$ for all 4 networks. Although they represented only $8.6 \%$ of the community population, commercial fishers maintained $18.1 \%$ of their ties with members of their own group in the CST network. Strong ties among commercial fishers were mostly occupational ties $(27.6 \%)$ and kinship ties $(19.4 \%)$. Consumption fishers also 
Table 6. Frequency distribution ( $\%)$ of strong ties within and between fisher and nonfisher groups. $\chi^{2} \mathrm{p}:{ }^{* * *} \mathrm{p}<0.001$.

\begin{tabular}{|c|c|c|c|c|}
\hline & \multicolumn{3}{|c|}{ Percentage of ties with } & \multirow[t]{2}{*}{ Total } \\
\hline & $\begin{array}{c}\text { Commercial fishers } \\
(\mathrm{n}=29)\end{array}$ & $\begin{array}{c}\text { Consumption fishers } \\
(\mathrm{n}=92)\end{array}$ & $\begin{array}{l}\text { Nonfishers } \\
(\mathrm{n}=215)\end{array}$ & \\
\hline \multicolumn{5}{|l|}{ Community strong-tie network $* * *$} \\
\hline Commercial fishers & 18.1 & 27.1 & 54.9 & 100.0 \\
\hline Consumption fishers & 8.8 & 32.4 & 58.8 & 100.0 \\
\hline Nonfishers & 7.9 & 26.2 & 65.9 & 100.0 \\
\hline \multicolumn{5}{|l|}{ Friendship network ${ }^{* * *}$} \\
\hline Commercial fishers & 9.5 & 61.9 & 28.6 & 100.0 \\
\hline Consumption fishers & 15.1 & 46.5 & 38.4 & 100.0 \\
\hline Nonfishers & 2.4 & 13.4 & 84.2 & 100.0 \\
\hline \multicolumn{5}{|l|}{ Occupation network $* * *$} \\
\hline Commercial fishers & 26.7 & 46.7 & 26.7 & 100.0 \\
\hline Consumption fishers & 11.4 & 48.8 & 39.8 & 100.0 \\
\hline Nonfishers & 4.4 & 27.1 & 68.5 & 100.0 \\
\hline \multicolumn{5}{|l|}{ Kinship network ${ }^{* * *}$} \\
\hline Commercial fishers & 19.4 & 20.2 & 60.5 & 100.0 \\
\hline Consumption fishers & 7.9 & 27.0 & 65.1 & 100.0 \\
\hline Nonfishers & 10.7 & 29.6 & 59.7 & 100.0 \\
\hline Percentage of individuals in each group & 8.6 & 27.4 & 64.0 & 100.0 \\
\hline
\end{tabular}

had a high percentage of friendship ties directed to commercial fishers (15.1\%). Furthermore, $61.9 \%$ and $46.7 \%$ of commercial fishers' friendship and occupational ties, respectively, were directed to consumption fishers, although this group represents only $27 \%$ of the population. Consumption fishers have a high percentage of ties with members of their own group, mainly friendship ties $(46.5 \%)$ and occupational ties (48.8\%).

\section{DISCUSSION}

We examined how food security can be linked to structural features of strong-tie social networks in one riverine village of the Brazilian Amazon that is dependent on fish as a key element of its diet. We used a whole-network approach that is richer than an egocentric network approach because it reveals the social structure created by all the relationships within a community rather than privileging the set of direct relations of any particular individual. This strategy allowed us to add to the literature on food security and social network analysis that uses egocentric networks data or proxy variables. Moreover, using the reciprocity of the tie as an empirical indicator of tie strength (Friedkin 1980), we focused on strong ties to reveal meaningful patterns of connectivity among villagers from a small and isolated community where most people know each other. Strong-tie friendship, occupational, and kinship networks were shown to be fragmented, with many isolated and small components. These results are in accordance with previous research that suggested that strong-tie networks tend to be fragmented into small, disconnected groups, each of which is composed of individuals with many ties to each other (Granovetter 1973, Friedkin 1980, Watts 1999, White and Houseman 2002). However, combining the three networks allows us to reveal that nearly all of the villagers are connected through strong ties in one large component. Weak ties have been frequently considered to act as bridges among dense clusters, connecting them to larger networks and drastically reducing the average distance between individuals (Granovetter 1973, Dodds et al. 2003, Watts 2004). In the CST network of Brasília Legal, individuals who have strong ties in more than one social dimension with different individuals act as connectors among friendship, occupation, and kinship clusters.

The analysis of the structural characteristics of this community network furthers understanding of the availability, access, utilization, and stability of the fish resources. There are numerous fishers in the community who are distributed widely in the social network in such a way that they are connected at very short distances with the entire village population. In Brasília Legal, as in other Tapajós riverine communities, it is a common practice to share fish catches among friends and extended family members, to exchange fish for other products or services, or to provide fish to individuals in need (Sampaio da Silva 2008, Sampaio da Silva et al. 2011). Relations of trust associated with strong ties, ensuring reciprocity and exchanges, can enhance the motivation to share resources at the community level. The overall pattern of connectivity through strong ties between the providers of the fish resources and the villagers appears, therefore, to be highly compatible with a widespread availability of fish as a resource that can be accessed by the entire community.

Healthy use of the resource through the selection of fish species with lower mercury concentrations for consumption is associated with the number of strong ties individuals maintain with other members of the community. A study with a small sample of the Brasília Legal population $(n=31)$ showed that this change in dietary habits was associated with a reduction in mercury exposure and some health improvements (Fillion et al. 2011). These results are in accordance with findings of numerous health studies on social capital and social support that showed that better health or well-being was associated with larger social networks, a higher number of friends, or more frequent contact with close family members (for a review, see Luke and Harris 2007).

Despite decades of fishing, the fish resources available to the fishers of Brasilia Legal in 2004 could still be considered abundant. Sustainable management practices based on trust and cooperation may have been favored by the strong-tie connectivity 
among fishers' groups from Brasília Legal (Pretty and Ward 2001, Bodin and Crona 2009, Prell et al. 2009). According to Grafton (2005), individual fishers connected through strong ties are inclined to trust each other and therefore comply with fishing rules and engage in cooperative and sustainable fishing practices. Trust and cooperative behavior among fishers may in turn contribute to more sustainable fish management practices (Gilmour et al. 2011) as well as to the long-term viability of fish stocks and sustainable access to a healthy fish diet (Jentoft 2000). Furthermore, in fishing communities connected by strong ties, villagers are also believed to be more likely to care about each other and therefore more likely to make equitable use of the fish resources (Jentoft 2000). Although friendship and occupational ties predominated among consumption fishers and between commercial and consumption fishers, kinship and occupational ties were more frequent among commercial fishers. The exploratory nature of our study prevents us from going further into the interpretation regarding the contribution of these different types of ties to fish resource management practices, but it points to the relevance of distinguishing among different types of strong ties in further studies.

The long-term stability of the fish resources may, however, mask shorter term cyclical variations in the availability of or access to the fish resources. In the Tapajós region, there are indeed intense seasonal variations in fish species availability (Lebel et al. 1997), mostly linked to ecological factors such as changes in water levels (up to $6 \mathrm{~m}$ ) between the rainy (December to March) and dry (June to September) seasons. However, the comparison of fish consumption in Brasília Legal among the 4 seasons associated with the hydrological cycle in the Tapajós region showed that the overall fish consumption is remarkably stable throughout the year (Passos et al. 2001). The seasonal stability in the fish resources is likely associated with the ability of the fishers to integrate ecological knowledge into adaptive fishing practices, allowing them to explore diverse aquatic ecosystems in response to the changing availability of fish species during the year.

\section{SPECULATION}

The previous arguments focused mainly on positive outcomes associated with community connectivity through strong ties. However, a dense network of strong ties among community members (intracommunity strong ties are commonly referred to as bonding ties, see Woolcock and Narayan [2000]) may also be linked to negative consequences (Portes 1998). Some studies support the perspective that a high network density within a group or community can be associated with homogenization and redundancy of the available information (Granovetter 1973, Bodin et al. 2006), decreased adaptive capacity (Bodin and Crona 2009), reduced openness to external opportunities (Newman and Dale 2007), and less innovativeness (Ruef 2002). Furthermore, because the high social investment associated with strong ties imposes constraints on the number of these ties an individual is able to maintain simultaneously (Scott 2000, White and Houseman 2002), a dense CST network can also hinder the establishment or maintenance of ties with actors outside the community. These external ties have been called bridging ties when they connect individuals from different groups at the same hierarchical level, e.g., ties between inhabitants of distinct communities, or linking ties when they connect different hierarchical levels of authority, e.g., ties between communities and governmental agencies at the municipal or national levels (Woolcock 2001, Dale and Newman 2010). External ties are often considered weaker relations and have been recognized as providing access to new information and resources of various types not available in the community (Granovetter 1973, Woolcock 2001).

As long as the Brasilia Legal village remained relatively isolated and had effective control over the surrounding ecosystems, a dense intracommunity network with few ties with external agents, organizations, or institutions may have been an adaptive social structure to ensure the sustainable management of the local fishing resources. However, in 2004, the year data were collected for our study, the community began to be affected by several external factors that considerably reduced its isolation and control over local ecosystems: the installation of a sawmill run by village outsiders, increased accessibility through a new unpaved road and through a high-speed boat to the nearby cities, and the intensification of industrial fishing (Demeda 2010, Fillion et al. 2011). Furthermore, data from 2006 (Fillion et al. 2011) show a decrease in fish consumption in the community, and other studies report a perceived decrease of fish availability in the region (Demeda 2010, Sampaio da Silva et al. 2011). The probable causes of the recent decrease in fish availability in the Tapajós region have been identified as changes that are mostly beyond the direct control of communities, such as fish stock depletion by professional fishers from outside the community and ecosystem impoverishment mainly associated with large-scale deforestation. In this new context of regional environmental changes, the Brasília Legal strong-tie network structure may have contributed to keeping the community in social isolation, hindering its influence on the decision-making processes that take place at the regional level and putting the local fish resources at greater risk. This view is supported by results from a case study on an African fishing community that had high levels of social capital quantified through social network analysis but lacked external contacts related to financial institutions and markets (Bodin and Crona 2008). In this community, although most of the villagers were aware of declining fish stocks, they were not successful in collectively regulating local fisheries in a sustainable way. However, additional data on external community ties and on the process of changes that began in 2004 is needed to fully address these questions in the case of Brasília Legal.

Brasília Legal is a traditional riverine Amazonian community. Colonist communities composed of recent migrants, mostly from northeastern Brazil, are also widely distributed along the Tapajós riverbanks. The characteristics of social structure in colonist communities and their implications regarding the management and use of fish resources in the Amazon region deserve future investigation. How gender relations contribute to the four dimensions of food security of riverine Amazonian communities is another priority for further research. Furthermore, because the fish sharing and exchange practices described in the Tapajós communities have been observed in fishing communities from other regions, e.g., the Caiçara communities of coastal Brazil (Hanazaki et al. 2013), we suggest that a whole-network approach is useful for studying the relation between community social structure and fish distribution in other small-scale fisheries. How community social networks intersect with fish exchange networks to explain food security is also a subject for further studies. Finally, 
we suggest that this approach is useful for studying the management and use of other resources under common property regimes, such as forest nontimber products, water supplies, or medicinal plants, and for exploring the role of social networks in contributing to food security in communities and organizations from different cultural origins and social and environmental contexts.

Responses to this article can be read online at: http://www.ecologyandsociety.org/issues/responses. $\mathrm{php} / 7483$

\begin{abstract}
Acknowledgments:
We express our deep gratitude to the villagers of Brasilia Legal for their hospitality and their participation and collaboration in fieldwork. We also thank J. S. Oestreicher for the production of the map in Figure 1. This work was financially supported by the International Development Research Centre (IDRC) of Canada, the Social Sciences and Humanities Research Council (SSHRC) of Canada, and the Community of Practice in Ecosystem Approaches to Health in Latin America and the Caribbean (CoPEH-LAC).
\end{abstract}

\section{LITERATURE CITED}

Adams, C., R. S. S. Murrieta, and R. A. Sanches. 2005. Agriculture and diet among riverine populations of the Amazonian floodplains: new perspectives (in Portuguese). Ambiente \& Sociedade 8:1-22.

Agrawal, A. 2001. Common property institutions and sustainable governance of resources. World Development 29:1649-1672. http://dx.doi.org/10.1016/S0305-750X(01)00063-8

Ahluwalia, I. B., J. M. Dodds, and M. Baligh. 1998. Social support and coping behaviors of low-income families experiencing food insufficiency in North Carolina. Health Education \& Behavior 25:599-612. http://dx.doi.org/10.1177/109019819802500507

Almeida, O. T., K. Lorenzen, and D. G. McGrath. 2009. Fishing agreements in the lower Amazon: for gain and restraint. Fisheries Management and Ecology 16:61-67. http://dx.doi.org/10.1111/ j.1365-2400.2008.00647.x

Barrett, C. B. 2010. Measuring food insecurity. Science 327:825-828. http://dx.doi.org/10.1126/science.1182768

Beaumier, M. C., and J. D. Ford. 2010. Food insecurity among Inuit women exacerbated by socio-economic stresses and climate change. Canadian Journal of Public Health 101:196-201.

Bebbington, A., and T. Perreault. 1999. Social capital, development, and access to resources in highland Ecuador. Economic Geography 75:395-418. http://dx.doi.org/10.2307/144478

Becquey, E., F. Delpeuch, A. M. Konaté, H. Delsol, M. Lange, M. Zoungrana, and Y. Martin-Prevel. 2012. Seasonality of the dietary dimension of household food security in urban Burkina Faso. British Journal of Nutrition 107:1860-1870. http://dx.doi. org/10.1017/S0007114511005071
Berkes, F. 2003. Alternatives to conventional management: lessons from small-scale fisheries. Environments 31:5-19.

Bodin, Ö., and B. I. Crona. 2008. Management of natural resources at the community level: exploring the role of social capital and leadership in a rural fishing community. World Development 36:2763-2779. http://dx.doi.org/10.1016/j. worlddev.2007.12.002

Bodin, Ö., and B. I. Crona. 2009. The role of social networks in natural resource governance: what relational patterns make a difference? Global Environmental Change 19:366-374. http://dx. doi.org/10.1016/j.gloenvcha.2009.05.002

Bodin, Ö., B. Crona, and H. Ernstson. 2006. Social networks in natural resource management: what is there to learn from a structural perspective? Ecology and Society 11(2): r2. [online] URL: http://www.ecologyandsociety.org/vol11/iss2/resp2/

Bodin, Ö., and C. Prell. 2011. Social networks and natural resource management: uncovering the social fabric of environmental governance. Cambridge University Press, Cambridge, UK. http:// dx.doi.org/10.1017/CBO9780511894985

Borgatti, S. P. 2002. NetDraw: graph visualization software. Analytic Technologies, Harvard, Massachusetts, USA. [online] URL: http://www.analytictech.com/ucinet.htm

Borgatti, S. P., M. G. Everett, and L. C. Freeman. 2002. Ucinet for Windows: software for social network analysis. Analytic Technologies, Harvard, Massachusetts, USA. [online] URL: https://sites.google.com/site/ucinetsoftware/home

Crona, B., and Ö. Bodin. 2010. Power asymmetries in small-scale fisheries: a barrier to governance transformability? Ecology and Society 15(4): 32. [online] URL: http://www.ecologyandsociety. org/vol15/iss4/art32/

Dale, A., and L. Newman. 2010. Social capital: a necessary and sufficient condition for sustainable community development? Community Development Journal 45:5-21. http://dx.doi. org/10.1093/cdj/bsn028

Demeda, K. 2010. Quanto vale uma "onça”? Os significados das relações entre os brasilienses e as suas paisagens na região do Tapajós, oeste do Pará. Dissertation. Universidade Federal do Pará, Belém, Pará, Brazil. [online] URL: http://ppgcs.ufpa.br/ arquivos/dissertacoes/dissertacaoTurma2008-KatiaDemeda.pdf

Dhokarh, R., D. A. Himmelgreen, Y.-K. Peng, S. Segura-Pérez, A. Hromi-Fiedler, and R. Pérez-Escamilla. 2011. Food insecurity is associated with acculturation and social networks in Puerto Rican households. Journal of Nutrition Education and Behavior 43:288-294. http://dx.doi.org/10.1016/j.jneb.2009.11.004

Díaz, H. L., R. D. Drumm, J. Ramírez-Johnson, and H. Oidjarv. 2002. Social capital, economic development and food security in Peru's mountain region. International Social Work 45:481-405. http://dx.doi.org/10.1177/00208728020450040601

Dodds, P. S., R. Muhamad, and D. J. Watts. 2003. An experimental study of search in global social networks. Science 301:827-829. http://dx.doi.org/10.1126/science.1081058

Dorea, J. D. 2003. Fish are central in the diet of Amazonian riparians: should we worry about their mercury concentrations? 
Environmental Research 92:232-244. http://dx.doi.org/10.1016/ s0013-9351(02)00092-0

Fillion, M., A. Philibert, F. Mertens, M. Lemire, C. J. S. Passos, B. Frenette, J. R. D. Guimarães, and D. Mergler. 2011. Neurotoxic sequelae of mercury exposure: an intervention and follow-up study in the Brazilian Amazon. EcoHealth 8:210-222. http://dx. doi.org/10.1007/s10393-011-0710-1

Food and Agriculture Organization of the United Nations (FAO). 2010. The state of food insecurity in the world. FAO, Rome, Italy.

Friedkin, N. 1980. A test of structural features of Granovetter's strength of weak ties theory. Social Networks 2:411-422. http:// dx.doi.org/10.1016/0378-8733(80)90006-4

Gilmour, P. W., P. D. Dwyer, and R. W. Day. 2011. Beyond individual quotas: the role of trust and cooperation in promoting stewardship of five Australian abalone fisheries. Marine Policy 35:692-702. http://dx.doi.org/10.1016/j.marpol.2011.02.010

Gochfeld, M., and J. Burger. 2005. Good fish/bad fish: a composite benefit-risk by dose curve. NeuroToxicology 26:511-520. http://dx.doi.org/10.1016/j.neuro.2004.12.010

Grafton, R. Q. 2005 Social capital and fisheries governance. Ocean \& Coastal Management 48:753-766. http://dx.doi. org/10.1016/j.ocecoaman.2005.08.003

Granovetter, M. S. 1973. The strength of weak ties. American Journal of Sociology 78:1360-1380. http://dx.doi.org/10.1086/225469

Hanazaki, N., F. Berkes, C. S. Seixas, and N. Peroni. 2013. Livelihood diversity, food security and resilience among the Caiçara of coastal Brazil. Human Ecology 41:153-164. http://dx. doi.org/10.1007/s10745-012-9553-9

Haythornthwaite, C. 1996. Social network analysis: an approach and technique for the study of information exchange. Library \& Information Science Research 18:323-342. http://dx.doi. org/10.1016/S0740-8188(96)90003-1

Jentoft, S. 2000. The community: a missing link of fisheries management. Marine Policy 24:53-60. http://dx.doi.org/10.1016/ S0308-597X(99)00009-3

Kossinets, G., and D. J. Watts. 2006. Empirical analysis of an evolving social network. Science 311:88-90. http://dx.doi. org/10.1126/science.1116869

Lebel, J., D. Mergler, F. Branches, M. Lucotte, M. Amorim, F. Larribe, and J. Dolbec. 1998. Neurotoxic effects of low-level methylmercury contamination in the Amazonian Basin. Environmental Research 79:20-32. http://dx.doi.org/10.1006/ enrs.1998.3846

Lebel, J., M. Roulet, D. Mergler, M. Lucotte, and F. Larribe. 1997. Fish diet and mercury exposure in a riparian Amazonian population. Water, Air, \& Soil Pollution 97:31-44. http://dx.doi. org/10.1023/A:1018378207932

Luke, D. A., and J. K. Harris. 2007. Network analysis in public health: history, methods, and applications. Annual Review of Public Health 28:69-93. http://dx.doi.org/10.1146/annurev. publhealth.28.021406.144132

Mahaffey, K. R. 2004. Fish and shellfish as dietary sources of methylmercury and the $\omega-3$ fatty acids, eicosahexaenoic acid and docosahexaenoic acid: risks and benefits. Environmental Research 95:414-428. http://dx.doi.org/10.1016/j.envres.2004.02.006

Marín, A., S. Gelcich, J. C. Castilla, and F. Berkes. 2012. Exploring social capital in Chile's coastal benthic comanagement system using a network approach. Ecology and Society 17(1): 13. http:// dx.doi.org/10.5751/ES-04562-170113

Marin, A., and B. Wellman. 2011. Social network analysis: an introduction. Pages 11-25 in J. Scott and P. J. Carrington, editors. The SAGE handbook of social network analysis. SAGE, Thousand Oaks, California, USA.

Marsden, P. V., and K. E. Campbell. 1984. Measuring tie strength. Social Forces 63:482-501. http://dx.doi.org/10.1093/sf/63.2.482

McGrath, D. G., O. T. Almeida, and F. D. Merry. 2007. The influence of community management agreements on household economic strategies: cattle grazing and fishing agreements on the Lower Amazon floodplain. International Journal of the Commons 1:67-87.

Mergler, D., H. A. Anderson, L. H. M. Chan, K. R. Mahaffey, M. Murray, M. Sakamoto, and A. H. Stern. 2007. Methylmercury exposure and health effects in humans: a worldwide concern. AMBIO: A Journal of the Human Environment 36:3-11. http://dx. doi.org/10.1579/0044-7447(2007)36[3:MEAHEI]2.0.CO:2

Mertens, F., J. Saint-Charles, M. Lucotte, and D. Mergler. 2008. Emergence and robustness of a community discussion network on mercury contamination and health in the Brazilian Amazon. Health Education \& Behavior 35:509-521. http://dx.doi. org/10.1177/1090198108320357

Mertens, F., J. Saint-Charles, and D. Mergler. 2012. Social communication network analysis of the role of participatory research in the adoption of new fish consumption behaviors. Social Science \& Medicine 75:643-650. http://dx.doi.org/10.1016/ j.socscimed.2011.10.016

Mertens, F., J. Saint-Charles, D. Mergler, C. J. Passos, and M. Lucotte. 2005. Network approach for analyzing and promoting equity in participatory ecohealth research. Ecohealth 2:113-126. http://dx.doi.org/10.1007/s10393-004-0162-y

Mertens, F., R. Távora, I. F. da Fonseca, R. Grando, M. Castro, and K. Demeda. 2011. Social networks, social capital and environmental governance in the Amazonian Gateway Territory. Acta Amazonica 41:481-492. http://dx.doi.org/10.1590/ $\underline{\text { S0044-59672011000400006 }}$

Mtika, M. M. 2001. The AIDS epidemic in Malawi and its threat to household food security. Human Organization 60:178-188. http://dx.doi.org/10.17730/humo.60.2.cnlpmfrrg8hay9xh

Murrieta, R. S. S. 2001. Dialética do sabor: alimentação, ecologia e vida cotidiana em comunidades ribeirinhas da Ilha de Ituqui, Baixo Amazonas, Pará. Revista de Antropologia 44:39-88. http:// dx.doi.org/10.1590/S0034-77012001000200002

Newman, L., and A. Dale. 2007. Homophily and agency: creating effective sustainable development networks. Environment, Development and Sustainability 9:79-90. http://dx.doi.org/10.1007/ s10668-005-9004-5

Ostrom, E., and C. Hess. 2007. Private and common property rights. School of Public and Environmental Affairs Research 
Paper No. 2008-11-01. Indiana University, Bloomington, Indiana, USA. http://dx.doi.org/10.2139/ssrn.1936062

Passos, C. J. S., and D. Mergler. 2008. Human mercury exposure and adverse health effects in the Amazon: a review. Cadernos de Saúde Pública 24(supplement 4):S503-S520. http://dx.doi. org/10.1590/S0102-311X2008001600004

Passos, C. J. S., D. Mergler, M. Fillion, M. Lemire, F. Mertens, J. R. D. Guimarães, and A. Philibert. 2007a. Epidemiologic confirmation that fruit consumption influences mercury exposure in riparian communities in the Brazilian Amazon. Environmental Research 105:183-193. http://dx.doi.org/10.1016/j.envres.2007.01.012

Passos, C. J. S., D. Mergler, E. Gaspar, S. Morais, M. Lucotte, F. Larribe, R. Davidson, and S. de Grosbois. 2001. Caracterização do consumo alimentar de uma população ribeirinha na Amazônia Brasileira. Revista Saúde e Ambiente 4:72-84.

Passos, C. J., D. Mergler, E. Gaspar, S. Morais, M. Lucotte, F. Larribe, R. Davidson, and S. de Grosbois. 2003. Eating tropical fruit reduces mercury exposure from fish consumption in the Brazilian Amazon. Environmental Research 93:123-130. http://dx. doi.org/10.1016/S0013-9351(03)00019-7

Passos, C. J. S., D. Mergler, M. Lemire, M. Fillion, J. R. D. Guimarães. 2007b. Fish consumption and bioindicators of inorganic mercury exposure. Science of the Total Environment 373:68-76. http://dx.doi.org/10.1016/j.scitotenv.2006.11.015

Portes, A. 1998. Social capital: its origins and applications in modern sociology. Annual Review of Sociology 24:1-24. http://dx. doi.org/10.1146/annurev.soc.24.1.1

Prell, C., C. Hubacek, and M. Reed. 2009. Stakeholder analysis and social network analysis in natural resource management. Society \& Natural Resources: An International Journal 22:501-518. http://dx.doi.org/10.1080/08941920802199202

Pretty, J., and H. Ward. 2001. Social capital and the environment. World Development 29:209-227. http://dx.doi.org/10.1016/ S0305-750X(00)00098-X

Rogers, E. 2003. Diffusion of innovations. Fifth edition. Free, New York, New York, USA.

Roulet, M., M. Lucotte, R. Canuel, N. Farella, M. Courcelles, J.R. D. Guimarães, D. Mergler, and M. Amorim. 2000. Increase in mercury contamination recorded in lacustrine sediments following deforestation in the central Amazon. Chemical Geology 165:243-266. http://dx.doi.org/10.1016/S0009-2541(99)00172-2

Ruef, M. 2002. Strong ties, weak ties and islands: structural and cultural predictors of organizational innovation. Industrial and Corporate Change 11:427-449. http://dx.doi.org/10.1093/icc/11.3.427

Saint-Charles, J., M.-E. Rioux-Pelletier, P. Mongeau, and F. Mertens. 2012. Diffusion of environmental health information: the role of sex- and gender-differentiated pathways. Pages 69-76 in Institute of Gender and Health, Canadian Institutes of Health Research, editors. What a difference sex and gender make: a gender, sex and health research casebook. Institute of Gender and Health, Canadian Institutes of Health Research, Vancouver, British Columbia, Canada. [online] URL: http://www.cihr-irsc.gc.ca/e/ documents/What a Difference Sex and Gender Make-en.pdf

Sampaio da Silva, D. 2008. Ressources halieutiques du Tapajós en Amazonie brésilienne: une étude écosystémique reliant les pratiques de pêche, les caractéristiques des bassins versants et la contamination au mercure. Dissertation. Université du Québec à Montréal, Montréal, Québec, Canada. [online] URL: http://www. archipel.uqam.ca/1060/1/D1657.pdf

Sampaio da Silva, D., M. Lucotte, and S. Paquet. 2011. Les connaissances au quotidien: perceptions et savoirs des populations riveraines de l'Amazonie sur leurs ressources halieutiques. Confins 13. [online] URL: http://confins.revues. org/7334

Sampaio da Silva, D., M. Lucotte, M. Roulet, H. Poirier, D. Mergler, E. Oliveira Santos, and M. Crossa. 2005. Trophic structure and bioaccumulation of mercury in fish of 3 natural lakes of the Brazilian Amazon. Water, Air, \& Soil Pollution 165:77-94. http://dx.doi.org/10.1007/s11270-005-4811-8

Sandström, A., and C. Rova. 2010. Adaptive co-management networks: a comparative analysis of two fishery conservation areas in Sweden. Ecology and Society 15(3): 14. [online] URL: http://www.ecologyandsociety.org/vol15/iss3/art14/

Scott, J. 2000. Social network analysis: a handbook. SAGE, Thousand Oaks, California, USA.

Turner, R. A., N. V. C. Polunin, and S. M. Stead. 2014. Social networks and fishers' behavior: exploring the links between information flow and fishing success in the Northumberland lobster fishery. Ecology and Society 19(2): 38. http://dx.doi. org/10.5751/ES-06456-190238

Walker, J. L., D. H. Holben, M. L. Kropf, J. P. Holcomb Jr., and H. Anderson. 2007. Household food insecurity is inversely associated with social capital and health in females from special supplemental nutrition program for women, infants, and children households in Appalachian Ohio. Journal of the American Dietetic Association 107:1989-1993. http://dx.doi.org/10.1016/j. jada.2007.08.004

Wasserman, S., and K. Faust. 1994. Social network analysis: methods and applications. Cambridge University Press, New York, New York, USA. http://dx.doi.org/10.1017/cbo9780511815478

Watts, D. J. 1999. Networks, dynamics, and the small-world phenomenon. American Journal of Sociology 105:493-527. http:// dx.doi.org/10.1086/210318

Watts, D. J. 2004. The "new" science of networks. Annual Review of Sociology 30:243-270. http://dx.doi.org/10.1146/annurev. soc. 30.020404 .104342

Wellman, B., and S. Wortley, 1990. Different strokes from different folks: community ties and social support. American Journal of Sociology 96:558-588. http://dx.doi.org/10.1086/229572

White, D. R., and M. Houseman. 2002. The navigability of strong ties: small worlds, tie strength, and network topology. Complexity 8:72-81. http://dx.doi.org/10.1002/cplx.10053

Woolcock, M. 2001. The place of social capital in understanding social and economic outcomes Canadian Journal of Policy Research 2:11-17.

Woolcock, M., and D. Narayan. 2000. Social capital: implications for development theory, research, and policy. World Bank Research Observer 15:225-249. http://dx.doi.org/10.1093/wbro/15.2.225 